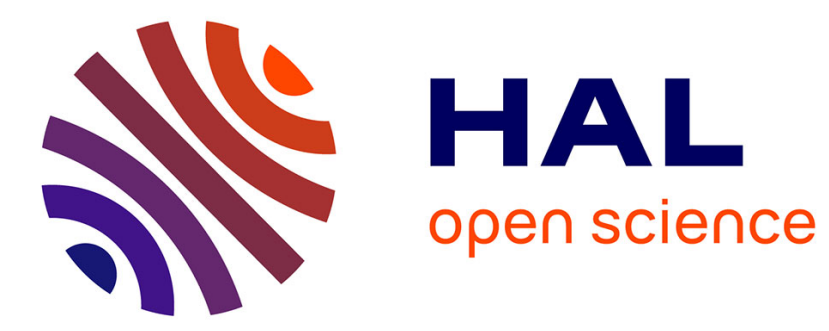

\title{
Challenging the Coproduction of Virtual Water and Palestinian Agriculture
}

\author{
Julie Trottier, Jeanne Perrier
}

\section{To cite this version:}

Julie Trottier, Jeanne Perrier. Challenging the Coproduction of Virtual Water and Palestinian Agriculture. Geoforum, 2017, 87, pp.85-94. 10.1016/j.geoforum.2017.10.011 . hal-02107699

\section{HAL Id: hal-02107699 \\ https://hal.science/hal-02107699}

Submitted on 27 Aug 2019

HAL is a multi-disciplinary open access archive for the deposit and dissemination of scientific research documents, whether they are published or not. The documents may come from teaching and research institutions in France or abroad, or from public or private research centers.
L'archive ouverte pluridisciplinaire HAL, est destinée au dépôt et à la diffusion de documents scientifiques de niveau recherche, publiés ou non, émanant des établissements d'enseignement et de recherche français ou étrangers, des laboratoires publics ou privés. 
Challenging the coproduction of virtual water and Palestinian agriculture

From the ground up

Authors: Julie Trottier (Julie.trottier@cnrs.fr); Jeanne Perrier (jeanne.perrier@sciencespo.fr)

Abstract:

The idiom of virtual water feeds a prolific literature now shaping the policies of national administrations and international organizations, including donors. This article explores the manner in which Palestinian agriculture and the concept of virtual water shed light on each other's coproduction. It opens the black box of virtual water to identify the underlying hypotheses. It invalidates these hypotheses using empirical research. Integrating structuration theory to an STS approach, it explores the manner the coproduction of an interpretive scheme, virtual water, is linked to the construction of a structure of power. Within the idiom of virtual water, flows exist only through the international trade of commodities while states are endowed with an annually renewed stock of water. We focus on the real flow of water from its emergence from the earth to its evapotranspiration by a cultivated plant. We demonstrate that social and political variables within water governance determine the volumes of virtual water flows far more than climatic or agronomic variables. The idiom of virtual water portrays Palestinian smallholders as inefficient water users while ignoring the manner they sustain food security and environmental sustainability. It legitimizes export oriented agribusinesses as their mode of production corresponds to the coproduction of the idea of efficiency that underlying the concept of virtual water. These results allow us to reconsider smallholder agriculture as it exists in Palestinian territories and what sort of policies can support it.

\section{Introduction}

The Middle East is considered a water scarce region and has been especially targeted by the discourse on virtual water. Allan has long urged Middle East states to devote their scarce water resources to non agricultural activities generating higher added value. He argued this would allow importing food from states better endowed with water resources, thus ensuring both environmental sustainability and food security. He designated the water necessary to produce such imported crops as "virtual water" because it was imported in a virtual manner together with the crops. (Allan, 1992) The idiom of virtual water has fed a prolific literature that is now contributing to shape the policies of national administrations and international organizations, including donors. (Barnes, 2013) 
Opening the black box of virtual water reveals it treats water as an immobile stock embedded in the natural resources of a state. Within the idiom of virtual water, flows exist only through the international trade of commodities. They do not include the real flow of water from its source, through the land where farmers grow their crops, to the point it evaporates. Naming, defining and mapping are acts of ontological politics. (Mol, 1999) Such acts shape power and authority. The rapid rise of the virtual water literature granted a scientific legitimacy to this concept, simultaneously cementing a social imaginary it embedded.

Science and Technology Studies (STS) have long demonstrated how knowledge and norms are co-produced. In other words, they are constructed through their mutual interactions. This means the manner we understand the world both results from and shapes the manner we wish to govern it. The term "coproduction" designates the manner the social order, on one hand, and our scientific understanding of the world, on the other hand, construct each other continuously. (Jasanoff,, 2004) Integrating feminist and post-colonial studies, STS explored the manner social orders are constructed and performed through various categories produced by science, such as race, gender or ethnicity. (Rajagopalan et al., 2017) It thus paid attention to the construction of legitimacy in scientific thought, in technological choices and in political action. (Jasanoff, 2017) This article explores the concept of virtual water as a scientific category that is co-produced together with the legitimacy of a specific form of agriculture.

This article explores the manner Palestinian agriculture, on one hand, and the concept of virtual water, on the other hand, shed light on their coproduction. It uses in depth fieldwork to challenge virtual water as a hegemonic interpretive scheme that is increasingly shaping our representation of sustainable agriculture and water management. We focus on the trajectories water can bifurcate into between the point it emerges from the earth until the point it leaves 
the system. ${ }^{1}$ We demonstrate that social and political variables within water governance determine the volumes of virtual water flows far more than climatic or agronomic variables. The decision processes, both collective and individual, that determine the paths water will flow into are embedded in both land and water tenure. Our results thus dispel several assumptions upon which the concept of virtual water relies. This article then explores the role this interpretive scheme is playing within a wider structure of signification that portrays agribusinesses embedded in global trade as the only legitimate and successful forms of farming. It demonstrates how it makes Palestinian smallholders appear illegitimate because the manner they sustain food security and environmental sustainability is portrayed as an inefficient use of water. This leads us to reconceptualize water differently. Treating it as a flow instead of a stock allows us to integrate the various institutions it flows through on its path between source and plant. It allows us to reconsider smallholder agriculture as it exists in Palestinian territories and what sort of policies can support it.

\section{Opening and locating the black box}

The term "virtual water" was initially coined to designate the water embedded in commodities, such as cereals, that could be traded. (Allan, 1992) This focus on trade distinguished the concept of virtual water from the pre-existing notion of hydric productivity. The concept relied on the substitutability of water. Water necessary to produce a crop was deemed to become available for another activity generating more added value if that crop was imported. Champions of virtual water, such as Hoekstra and Chapagain, argued that water scarce states should import water intensive commodities such as food to "save" their resources. They argued that estimating the amount of water needed to produce different crops

\footnotetext{
1 Water leaves the system either through evapotranspiration through the leaves of plants, through evaporation from the soil or through reaching a sink such as the sea
} 
in various countries was necessary to guide such states' commercial and agricultural policies. They developed a method based on FAO data on crop water requirements and crop yields. (Hoekstra and Hung, 2005, p. 47) It considers that the average specific water demand (SWD) for a given crop (c) in a given state (n) could be calculated by dividing the crop "water requirement" (CWR) with the crop yield (CY):

$$
S W D[n, c]=\frac{C W R[n, c]}{C Y[n, c]}
$$

The data from the FAO had not been designed to produce calculations of virtual water volumes. It aimed to inform farmers of the maximum yields as a function of irrigation calendars. Using it in this fashion, Hoekstra and Hung were turning it upside down. Their equation supposes that the irrigation calendar deemed by the FAO to maximize yield is systematically used by the farmers. The epistemic community that followed Hoekstra, which we will refer to as the "Delft school of thought", produced a prolific literature to assess the amount of virtual water contained in imported and exported crops. It applied this calculation method without challenging the underlying hypotheses.

These underlying hypotheses where rather extraordinary and wide sweeping. Such a calculation relies on the assumption that water is available on request for every farmer. Otherwise, farmers cannot provide the irrigation calendar that matches the specific water demand as it appears in the calculation method. This method also assumes that every farmer aims to maximize the vegetal mass. It assumes a monoculture on every plot of land. It assumes that a given crop only yields one product. It assumes that water serves only one use: the evapotranspiration of the crop that will be sold. Finally, it assumes that only climatic and agronomic variables determine the quantity of water that is necessary to produce a crop.

Such hypotheses rarely resist scrutiny. Agribusinesses with reliable and sizeable infrastructure may benefit from a supply of water on request when operating in very favorable conditions. Palestinian smallholders rely instead on shared springs or farmer managed 
shallow wells. In the Mediterranean area, spring flow varies widely through the year. This constrains the amount of water a farmer can access, as does the social organization allowing the farmer to access this spring. All Palestinian springs used in irrigation are shared according to "water turns". These are measured in terms of time periods during which the full flow of the spring is usually channeled towards a farmer's plot. Similarly, farmers relying on wells need to share with their neighbors, which constrains their access. As a consequence, most farmers either under irrigate or over irrigate in comparison with the ideal irrigation calendar embedded in the calculation of virtual water volumes. The Delft school recognized its general overestimation of the virtual water content of crops but didn't quantify it. (Chapagain and Orr, 2009, p.1220) Moreover, farmers rarely aim to maximize vegetal mass. They usually prefer maximizing revenue, a goal that sometimes proves to be contradictory with maximizing vegetal mass. Field observation also shows that Palestinian farmers often mix crops within a single plot and often derive two products from the same crop. For example, corn provides cobs that are commercialized while the remaining stalks provide pasture for sheep. Only scientists who have never observed farmers may assume water has only one use. In Egypt, farmers need water to wash the salt off the land otherwise it becomes sterile. (Barnes, 2013, p. 379) Palestinian greenhouse farmers use water in July and August to sterilize the soil. Finally, hypothesizing that climatic and agronomic variables alone determine the quantity of virtual water means assuming that water never flows through human institutions. This begs the question of how water reaches a plot of land after being abstracted. It constitutes a crucial part of the ontological politics of virtual water and will be challenged in the remainder of this article.

The coproduction of virtual water accommodated questionable assumptions because they were convenient for the epistemic community that championed it. Its calculation method proposed that virtual water flows could be detached from their contexts. This created the 
fictitious mobility of the concept. The controversy surrounding the underlying hypotheses constitutes a clear-cut case of ontological politics. This term designates conflicts involving different assumptions about what exists. (Forsyth and Levidow, 2015, p. 141) Several hypotheses, however challengeable, proved very useful for the rapid rise to hegemony of the concept of virtual water and its accompanying calculation method. Many have demonstrated the inaccuracy of the assumption concerning the distinction between green water, naturally occurring in the soil, and blue water, channeled to the soil through irrigation. (Fernandez, 2008, p. 54) (Perry, 2014, p. 121) Yet, calculations of the water footprint, an indicator the Delft school argues is wider than that of virtual water because it makes explicit the source of water that is used, rely on this distinction. (Hoekstra, Chapagain et al., 2011, p. 167) The Delft school coined the term water footprint to describe the virtual water content embedded in products when they are consumed. It kept the term virtual water to describe water consumed through the production of the goods. The assumption concerning substitutability of water implied that imported virtual water would free up existing water for uses generating greater added value. Yet, examples abound that contradict this assumption. In the 1990s, in Jericho, the casino and the Intercontinental hotel channeled water previously used in irrigation to services deemed to generate a greater added value but most of this revenue actually left Jericho and the Palestinian economy as soon as it materialized. (Trottier, 1999)

The epistemic community that promoted virtual water was concerned with international trade. It coalesced at a time when states had set up large databases concerning importations and exportations. In the 1990s, widespread computational capacities also appeared. This corresponded to a time when the FAO produced its own CROPWAT model that linked agronomic variables with climatic variables accessible online from climate stations around the world. As the databases were collected by states on a national scale, they allowed calculations concerning trade among states. This contributed to the shape global food models 
adopted. (Leblond and Trottier, 2016) Similarly, it shaped the discourse on virtual water, presenting virtual water flows as necessarily calculated over a national scale.

Such a discourse appealed to those who perceived the world as a set of nation states constituting the only forms of social organization capable of exercising power on the national as well as the international scenes. State policy makers were embedded in such institutions. Scientists usually adhered to this representation, aligning mostly with either of two groups : those subscribing to neo-liberal ideas and those broadly self described as Marxists. The first group supported an agenda according to which the future depended on such international trade. The second group considered that the forms of social organisation described in this article were inevitably doomed because Capital was going to appropriate their resources. (Harvey, 2010) The only disagreement between them laid in whether this was the end point. Both groups disregarded the actual forms of social organisation determining land and water tenure.

A few studies explored virtual water flows among large provinces, such as among the 19 water management areas in South Africa. (Dabrowski, Masekoameng et al., 2009) In such cases, large databases were already available, allowing the calculation over that scalar level. Thus, availability of data determined the scalar level of the calculations, rather than scientific reasoning. Few pointed out the inadequacy of such a scalar level to produce meaningful information. (Wichelns, 2015, p. 401)

The calculation of virtual water is a form of commensuration that proved very popular because it empowered a specific epistemic community. Commensuration means measuring a wide range of variables along the same metric. It may allow comparison when what is measured corresponds to instrumental values but it necessarily distorts substantive values. (Espeland, 1998) For example, attributing an economic value to a plot of land seems appropriate for an investor aiming for land speculation. It seems inappropriate for a 
landholder investing emotional value in his land. The concept of virtual water attributes only a very narrow instrumental value to water. This value is strictly economic and involves only one user dissociated from the context in which he farms. This creates the substitutability of water which allows extracting it from its context. Yet, when considered over an appropriate scalar level, water appears clearly embedded within substantive values. For example, many Palestinian farmers access water free of charge on the basis of a common property regime developed within the village. To them, water can neither be sold nor bought. It is not substitutable. Moreover, those Palestinian farmers who access water from "well companies" pay for "water hours", yet, they most often benefit from a "payment plan" when they cannot pay. This means that water is made available for them free of charge by their neighbors. Palestinian communities and families privilege maintaining local solidarity over profitability of a well. This is a substantive value. It resists commensuration. The Delft school could thrive because the epistemic community promoting it viewed water as an economic good and did not explore irrigation over such a scalar level. This allowed the persistence of underlying hypotheses that do not resist scrutiny.

How do Palestinian agriculture and the concept of virtual water shed light on each other's coproduction? In other words, how does virtual water portray Palestinian agriculture? And how does Palestinian agriculture reveal the power structure that is promoted by the concept of virtual water? When scientists produce scientific claims, they implicitly embed within them the power structures they take for granted. A largely social process then transforms this scientific claim into a scientific fact, thereby "blackboxing" it. (Latour, 1987) Opening the black box of virtual water allows us to show a power structure is embedded in the concept and its accompanying calculation method. Scientists thus reify a political structure. In the case of virtual water, scientists reified a state control over water that rarely exists. They reified an international virtual water trade that would be responsible for food 
security. Confronting how virtual water depicts Palestinian Agriculture with the results that emerge from fieldwork sheds light on this process.

Deploying the idiom of virtual water to examine Palestinian agriculture leads us to project a homogeneity over the entire territory. It leads us to project scarcity everywhere, ignoring the islands of water abundance that dot the landscape. Palestinian irrigation has been developed from springs managed as common property resources (CPRs) and from wells managed as commons by farmers. The scale over which farmers operate is far smaller than the national territory and their regulation of water access is based on more than economic calculation alone. The idiom of virtual water projects agribusiness practices over the territory, where water is supposed to be bought as an input according to a cost/benefit calculation. The idiom of virtual water doesn't ask where water comes from nor what are the rules to access and to use it. Its inherent distinction between blue and green water assumes that, where green water is abundant, irrigation will be diminished. Fieldwork in the West Bank reveals the opposite. Villages using reliable wells do not practice rainwater harvesting. Where blue water is abundant and cheap or free, farmers rely less on green water, no matter how abundant it is.

Examining Palestinian agriculture to question virtual water shows that this concept treats water as a stock instead of a flow. The calculation method focuses on determining a quantity embedded in a crop. This is a stock. The mobility of the crop is equated with the mobility of that stock. This is why that literature refers to virtual water flows. Examining how water really flows in agriculture is a different matter. From the moment water is abstracted in a well or channeled from a spring, until the point it is evapotranspired through the stomata of a plant, it flows uninterruptedly. Following that trajectory shows water goes through a variety of human institutions. That trajectory determines the appropriate scalar level of analysis. This is the scalar level over which decisions will be made concerning irrigation and water appropriation and management. The second part of this article develops such an approach. 


\section{Following the trajectory of water}

What happens to water between the moment it emerges from the earth and the moment it evapotranspires through the stomata of a plant? Human and nonhuman actors direct this uninterrupted flow into a variety of trajectories. For example, water may be abstracted from a well managed by a Palestinian "well company", i.e. by a shallow well managed by a collective of farmers owning shares of this company. This locally built institution channels water to a plot whose farmer pays a set fee for one hour of irrigation. This water leaks partly along the network and infiltrates the soil. This leak constitutes a trajectory where part of the abstracted water is "lost" to the farmer paying for the water hour but "gained" by the field that is thus inadvertently watered. This trajectory channels either a non recoverable fraction of the initial full flow into the aquifer acting as a sink, or a recovered fraction to subordinate neighbor consumption. (Lankford, 2013, pp. 147-149) Such a case occurs, for example, if this leaked water is consumed by rainfed olive trees in a neighboring plot.

Once the remaining flow reaches the intended field, part of the water may irrigate the lemon trees serving as a marker dividing plots while the rest of the flow irrigates the avocado trees cultivated in that plot. The water consumed by the lemon trees follows a third trajectory called non-process beneficial consumption while the water consumed by the avocado trees follows a fourth trajectory called process beneficial consumption. A comprehensive examination of the trajectories this water can possibly adopt shows a total of 16 possible paths for water abstracted by the farmer. (Lankford, 2013, pp. 147-149) Diverting water from one of these trajectories into another one can appear to free up water for human and non human actors. These potential gains make up the paracommons. The term includes para to designate the fact resources are potentially available through "efficiency" improvements. It also 
includes commons to designate the fact that such resources involve a group of users.

(Lankford, 2013, pp. 5-16) Channeling a greater proportion of the water flow into one trajectory means reducing the flow into another trajectory.

Our representation of the world constructs our definition of efficiency. How we value one or other of these flows determines our definition of efficiency. For example, a classical definition shows efficiency as the ratio of beneficial consumption, i.e. the volume of water consumed via evapotranspiration of the plants that are cultivated, over the total volume of water that is withdrawn. Another definition of efficiency may show it as the ratio of the beneficial consumption over the total volume of irrigation water that is consumed. Both types of efficiencies could be raised in our earlier example if the lemon trees where chopped off and the leaks repaired. However, this enhanced efficiency could occur simultaneously with an increase in water consumption if the same volume of water keeps on being abstracted. (Lankford, 2013, pp. 47-49) This could occur, for example, if the farmer plants more avocado trees after having chopped off the lemon trees.

Increases in efficiency of water use can be detrimental to food security. Lemon trees serve commonly as dividers between siblings' plots in the West Bank. The lemons they produce provide a useful source of vitamin $\mathrm{C}$ to these families. More crucially, khubbiza, a local variety of mallow, commonly grows as a weed in irrigated fields. Palestinian custom considers that these plants should be available to all because they are not cultivated, thus are not produced through human labor. Anyone asking for a landowner's permission to enter his plot in order to pick khubbiza usually receives it. This very nutritious plant provides an important component to the poor's diet. It also generates income for the poor who can pick it and sell it. Thus water that is "lost" as beneficiary consumption in the cultivation of avocadoes may play a very beneficial role in local food security. 
Virtual water may represent an increased efficiency in the use of water that is managed as a stock. However, many Palestinian farmers are more constrained by flow management than by stock management. Any reticulation network faces two types of constraints: flow and stock. Farmers in Ain al-Baida, Kardala and Bardala, in the north of the Jordan Valley, are supplied with a constant flow of piped water by the Israeli company Mekorot, as replacement for the springs that dried up when that company sank wells in that village in the early 1970s. (Trottier, 2015) Their main constraint is flow. They cultivate trees that need irrigation in the summer but are rain fed in winter. They use the flow at their disposal to grow vegetables in greenhouses and in open fields during the winter. This allows them to maximize the use of a constant flow all year round. This is a rational decision to maximize income. But doing this, they do not maximize the use of the yearly stock of water at their disposal. In theory, the overall stock of water they access could allow them to grow a greater vegetal mass as most of their land remains unirrigated and uncultivated. This is not an option for them. Calculating virtual water according to the existing methodology misrepresents the constraints they face. Following the uninterrupted trajectory of water from the moment it is abstracted, through the many bifurcations it meets, until the point where it evapotranspires allows us to question several aspects of virtual water. The relevant scale over which we need to calculate it, in terms of space and time, changes significantly. Similarly, following this uninterrupted trajectory demonstrates the importance of the decision processes through which water travels before it becomes virtual.

\subsection{Palestinian cucumbers: an illustration}

Cucumbers are a widespread crop throughout the West Bank, which allows comparisons between various ecoregions. The standard calculation of virtual water embedded in cucumbers produced in the West Bank projects a homogeneity over the entire territory. 
Everywhere, producing a ton of cucumbers is supposed to have consumed 69 cubic meters of water. This value was calculated using the average of two values for virtual water content for cucumbers in Israel both published by Chapagain and Hoekstra in 2004 and Chapagain and Hung in 2002 respectively (Chapagain and Hoekstra, 2004; Chapagain and Hung, 2002) and a coefficient of 0,78 to account for cultivation in a greenhouse. ${ }^{2}$ (Fernandez, Bonacela et al., 2010) Field work carried out in 2014 and 2015 interviewing farmers to reconstitute their irrigation calendar allowed us to estimate the actual volume of water they used and consumed to produce their crop. Map 1 illustrates these results in the case of farmers all using relatively small, piped networks and growing cucumbers in greenhouses using drip irrigation. We initially assumed that the losses on the path between the source and the plant were negligible. We triangulated our calculations with field measurements of the volume of water flowing from the drippers at the head, middle and tail of the networks. These measurements validated this assumption.

\footnotetext{
2 The web tool of the Water footprint network produces a different value $\left(33.1 \mathrm{~m}^{3} /\right.$ ton of blue water $+58.1 \mathrm{~m}^{3} /$ ton of green water) for cucumbers in the West Bank, "Water footprint assessment tool: Production assessment", http://waterfootprint.org/en/resources/interactivetools/water-footprint-assessment-tool/ (accessed 18 November 2016). The web tool only presents values for open field cultivation. Greenhouse conditions reduce evapotranspiration by $22 \%$. The value from the web tool thus yields $70,9 \mathrm{~m}^{3} /$ ton for cucumbers in greenhouse conditions. In any case, using the figure from the web tool or from the standard valued averaging $69 \mathrm{~m}^{3} /$ tonne does not change any point in the discussion that follows.
} 


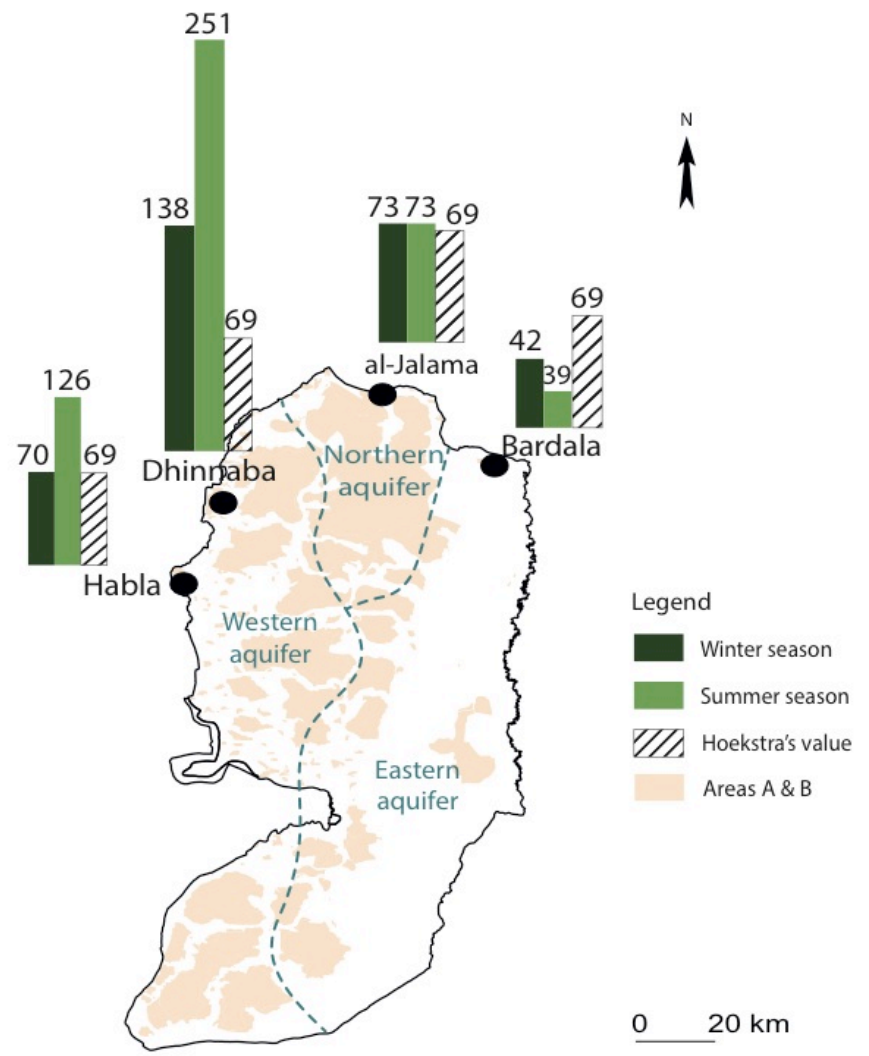

Map 1: Average quantity of virtual water for one ton of cucumbers $\left(\mathrm{m}^{3} / \mathrm{ton}\right)$ four villages located across the three main aquifers of the West Bank discussed in this article. The values labeled "Winter season" and "Summer season" are measured on site.

\begin{tabular}{|c|c|c|c|c|}
\hline Village & $\begin{array}{c}\text { According to } \\
\text { standard method }\end{array}$ & $\begin{array}{c}\text { Measured on site } \\
\text { Winter season }\end{array}$ & $\begin{array}{c}\text { Measured on site } \\
\text { Summer season }\end{array}$ & No of plots \\
\hline Habla & 69 & 70 & 126 & 3 \\
\hline Dhinnaba & 69 & 138 & 251 & 14 \\
\hline Al-Jalama & 69 & 73 & 73 & 3 \\
\hline Bardala & 69 & 42 & 39 & 2 \\
\hline
\end{tabular}

Table 1 - Average volume of virtual water in cucumbers in $\mathrm{m}^{3} /$ ton in each of four West Bank villages

Map 1 shows virtual water embedded in cucumbers as an average of the values emerging from our field work in each of four villages, Habla, Dhinnaba, Al-Jalama and 
Bardala, located across the three main aquifers of the West Bank. The volumes of virtual water embedded in cucumbers appear in Table 1. The measured values demonstrate (1) a significant variability compared with the values calculated using the standard method, (2) a significant variability across space and (3) a significant variability across seasons. The Delft school acknowledged the variability of the virtual water content of a crop within the territory of a large state. (Chapagain and Orr, 2009, p. 1220) Our results demonstrate a great variability within a very small territory. While Bardala farmers demonstrate a greater efficiency than expected by the standard calculations, Dhinnaba summer cucumbers consume over four times the volume expected through the standard calculations. Agronomic variables are constant here. However, climate variables vary between these locations. Bardala is located in the Jordan Valley, 100 meters below sea level, but Dhinnaba is located 100 meters above sea level on the western slope of the West Bank. Such variability through space cannot be determined by climatic variables alone, however, as is illustrated by the differences between Habla and Dhinnaba, both located in the same ecoregion. Dhinnaba cucumbers consume about twice as much water as Habla cucumbers both in winter and summer seasons. This dispels the hypothesis that agronomic and climatic variables alone account for virtual water embedded in a crop.

These results raise the question of which other variables may explain such diversity in the water footprint of Palestinian cucumbers. We included, in the measurement of water consumed to produce the crop, the volume farmers use to sterilize the soil at the height of summer. This practice involves trapping the water flowing from the drippers under plastic sheeting spread on the soil of the greenhouse. The heat then rises to such a level that the soil is sterilized. This water is not evapotranspired by the plants but it is used to grow the crop. This water is "lost" by the farmer as it follows the trajectory of a "non-recoverable fraction" (Lankford, 2013, pp. 148-149) and seeps into the soil or evaporates. These results 
demonstrate the crucial need to include the practices of the farmers when determining the calculation method of virtual water volumes. All of the farmers we interviewed used the same sterilizing practice. Subtracting the volume used to sterilize the soil from their overall water consumption would still yield the same diversity among the water footprints of their cucumbers.

Documenting the irrigation calendars used by the farmers demonstrates the variability of virtual water through time. The Delft school has admitted that crop water use depends on the crop calendar and that multiple crop calendars coexist in a single region. (Chapagain and Hoekstra, 2011, p. 750) Yet, it has not integrated this recognition in the calculation method of the virtual water embedded in a crop. Our results demonstrate that the variability between seasons is by itself variable through space. Figure one illustrates the water consumption of two farmers each growing the same variety of cucumbers over one dunum in the same greenhouse over two seasons, in two different villages. They both consume twice as much water in one season compared to the other. Yet one produces yields per cubic meter of water for the two seasons that are comparable. The other has $1 / 3$ difference in his yields.

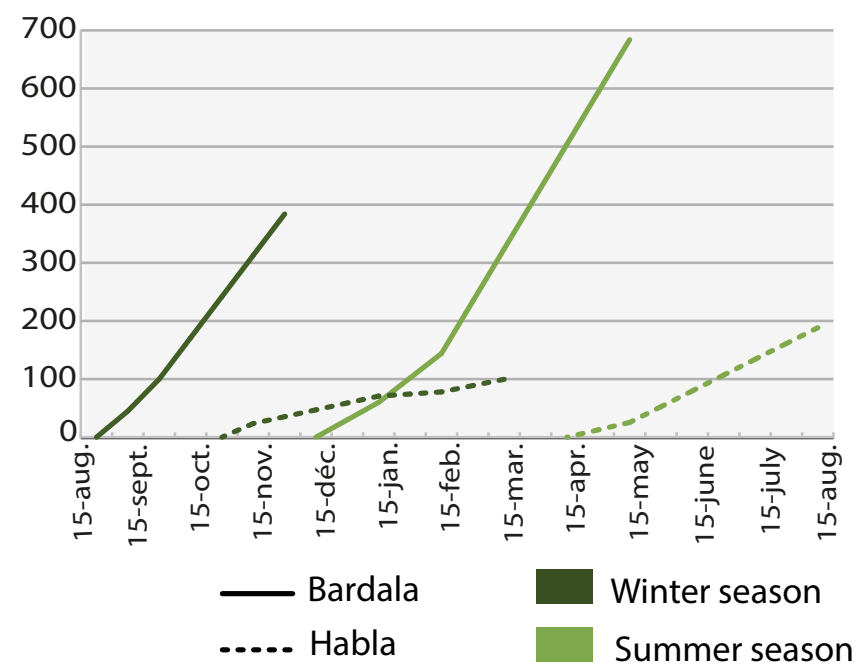

Figure 1: Water volume $\left(\mathrm{m}^{3}\right)$ used per dunum and per season to produce 1 ton of cucumbers in each of two West Bank villages: Bardala and Habla 


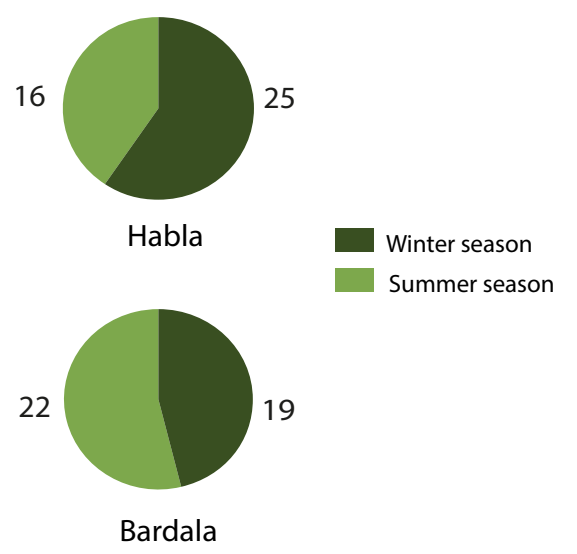

Figure 2: Yield of cucumbers $(\mathrm{kg})$ per cubic meter consumed during each season in each of two West Bank villages: Bardala and Habla

Farmers pick the cucumbers in their greenhouses over several months, producing a few boxes every day. A cucumber picked early in the season did not require the same amount of water as a cucumber picked late in the season. This has never been recognized in the calculations of virtual water flows because the present methods treat virtual water as a stock. Recognizing that water flows, as illustrated in Figure 1 shows the evolution over time of the virtual water embedded in a cucumber according to the time it is picked. Representing virtual water in this manner leads to policy recommendations that are different from representations of virtual water as a stock. This is explored in the third part of this article.

Institutional as well as individual decision processes guide water through its path, deviating it into either of the 16 trajectories mentioned above. As water flows from the earth to the plant through material infrastructure, it also flows through a variety of property regimes. Palestinian farmers manage their springs and wells as typical CPRs. Yet, when the water reaches their plot or their birka, i.e. their individual pool, it becomes private property. Map 2 illustrates the great variability of virtual water embedded in the cucumbers produced by different farmers all using greenhouses in the village of Dhinnaba in 2015. 


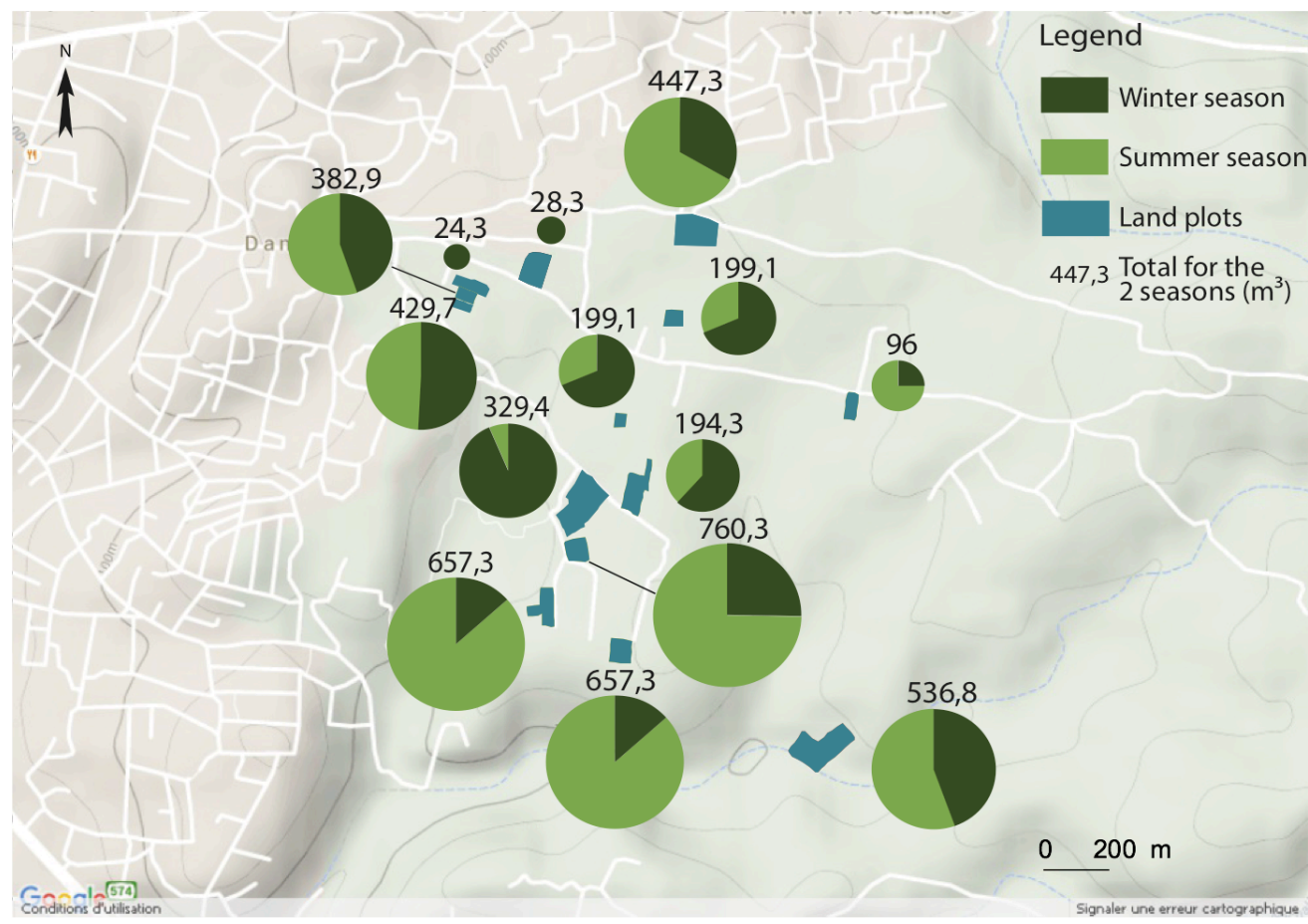

Map 2: Virtual water content $\left(\mathrm{m}^{3}\right)$ per farmer and per season in the West Bank village of Dhinnaba for 1 ton of cucumbers

The climate doesn't vary within the village and the agronomic variables are identical. This variability can only result from other factors, such as calendar's differences, the source of water and individual strategies. These farmers receive water from different local wells all managed in a similar fashion through "well companies" run by farmer-owners. Dhinnaba farmers carry out stock management, as opposed to the Bardala farmers constrained into flow management. In Dhinnaba, each farmer purchases hours of water from one well to which his plot is connected. A farmer phones the well operator a day ahead to ask for a slot to receive one hour of water. He is billed monthly by the well accountant for the number of hours he has used. The well companies in Dhinnaba sold their water in 2015 at an hourly rate varying from 80 to 100 New Israeli Shekels. As the flow varied from well to well, this meant a price varying from 1 to 1,33 New Israeli Shekels per cubic meter. Each well has a yearly quota, so farmers irrigate only when they consider their crop needs it. As opposed to their colleagues in 
Bardala, Dhinnaba farmers are free to use more one month and less the next one. Each farmer follows different practices according to his situation. Some are full time farmers, others are civil servants who finish work at 14:00 and farm in the afternoon. Some inherited their land from their fathers, some rent it, others bought it. This led them to adopt different practices with very different formal efficiencies that led to very different water consumptions. Social and economic variables thus appear to determine the volumes of virtual water embedded in a crop far more than climatic and agronomic variables.

The social and political mechanisms affecting the volumes of virtual water embedded in a crop need to be examined. Observing the flow of water along its path from the earth to the plant reveals these mechanisms. Each village has a distinct history shaping its water tenure and land tenure. From 1950, when they divided their tribal land into private plots, until 1967, all of Bardala irrigating farmers held rights to a water "turn" from one of 15 springs shared with Ain al-Baida and Kardala villages. The population fled to Jordan during the war of 1967. Those owning the land appropriated by Mehola, an Israeli settlement, were unable to come back to farm it again. In Bardala, absentee water right holders were kept on the list for the water "turns". Anyone wishing to use the turn of an absentee must rent it for a year at a price decided collectively within the village. This practice continues to this day in spite of the fact that all the springs disappeared in 1972 after the Israeli water company, Mekorot, drilled a well in the village. Since then, Mekorot, having recognized its responsibility for the disappearance of the springs, provides a constant flow of water in gauges located exactly where the springs used to flow. Farmers replicated over the gauges the common property regime previously deployed over the springs.

In neighboring Ain al-Baida, absentees were removed from the water "turns". Those villagers able to return home benefited from a shorter rotation of the spring's use. They decided they would include the returnees anew within this rotation once they came back. In 
2014, a Bardala farmer wishing to rent the water turn of an absentee paid the right holder an annual fee of 400 Jordanian Dinars. ${ }^{3}$ The right holder was often born abroad and had never seen the village. Consequently, Bardala farmers, who access water at a sizeable cost, make different decisions from their neighbors in Ain al-Baida, who access it for free. Similarly, the complex land tenure entails a variety of choices concerning water use. In Al Jalama, a farmer who cultivates his cousin's land does not pay rent because the land belongs to his family. Yet, he pays the absentee landowner's fee to the Israeli Authorities because his cousin is forced in exile as a refugee. Throughout the Jordan Valley, many farmers are sharecroppers but on the western side of the West Bank, most people either rent or own the land they farm. These various forms of land tenure systematically affect the decisions made concerning the 16 types of pathways water will be allowed to follow between the moment it emerges from the earth and the moment it reaches the plants. This determines the volume of virtual water embedded in a crop.

The construction of the separation wall since 2002 and the rapid urban sprawl around Palestinian villages is now driving the interaction between water tenure and land tenure. Map 3 shows the village of Habla, where much of the agricultural land now lays on the "wrong" side of the wall.

\footnotetext{
${ }^{3}$ In 2015, 400 Jordanian Dinars were equivalent to 560 US dollars. This is a sizeable sum for a farmer. As a matter of comparison, Palestinian agricultural labor in the Jordan Valley was remunerated 50 New Israeli Shekels per day of work by both Israeli settlements and Palestinian land owners. This daily wage amounted to 13 US dollars. Renting one mawdud of water, i.e. one unit of a water rotation from a gauge, was thus equivalent to the wages for 43 full days of work.
} 


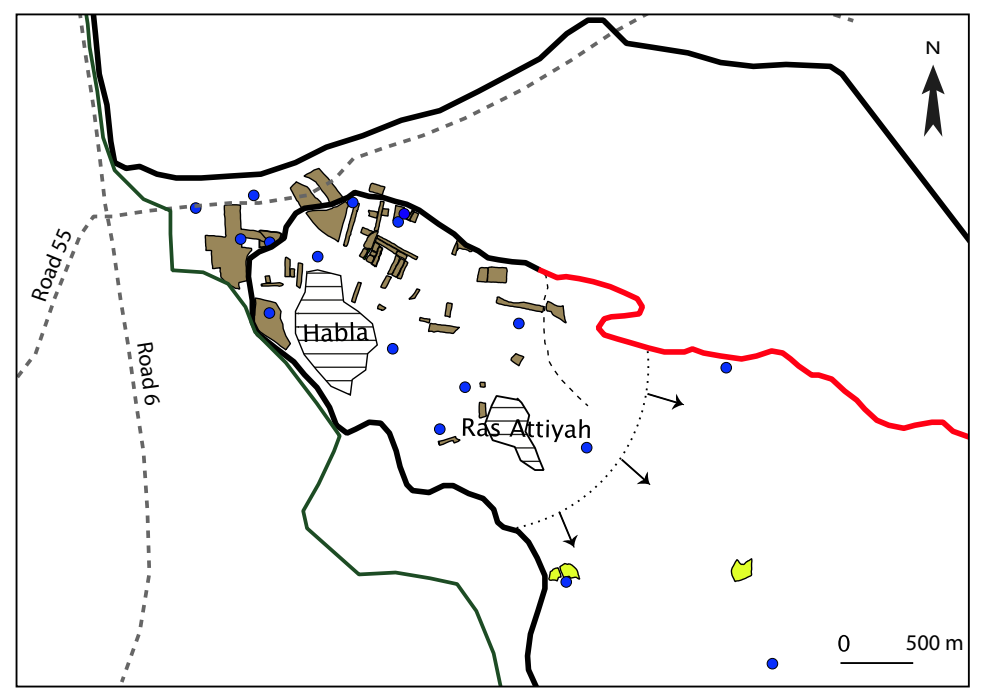

Legend

Land Plots

$\square$ Newly farmed

Urban area

- Wells

- Separation wall

- Modified wall

- Green Line

.... Israeli roads

$\uparrow . .$. Pioneer front

Map 3: Land and water uses in the West Bank village of Habla - the colored plots and the wells were the sites where investigations and measurements were made in this village Each plot is linked to a specific well managed by a local "well company". The land lying on the other side of the wall becomes difficult or impossible to access for a farmer. Depending on its location, its irrigation or its cultivation sometimes becomes forbidden. Simultaneously, land lying inside the wall but close to the heart of the villages of Habla and Ras Attiya becomes prey to urban sprawl. As a result the wells that supplied these lands are less solicited than they used to be. They now abstract far less than their quota. Farmers in quest of land now develop a "pioneer front" east and north of Ras Attiya, where land remains available. They build terraces where sheep had roamed through rain fed olive trees until recently. They connect to wells closest to their new plots. These wells have become oversubscribed and cannot satisfy all the users even when operating at full capacity. Under-irrigation thus increases. The quotas are attributed to individual wells, not to the entire area. So a well that under-pumps its quota cannot transfer its quota to an over-solicited well. The technical constraints of these wells also limit their pumping capacity in any case.

These interactions between land and water tenure impact the flow of water between the moment it is abstracted in wells in Habla and the moment it reaches the stomata of cultivated plants to evaporate. Neither the 2002 water law nor the 2014 decree 14 relating to 
the water law, both promulgated by the Palestinian Authority have been implemented in the West Bank. The Palestinian Authority does not have the institutional capacity to exercise social control over the management of water. This does not mean that water is not managed efficiently. Farmer run "well companies" and commons managing springs both show a great efficiency. But their definitions of efficiency diverge from the definition underlying the concept of virtual water and its standard calculation method.

\section{The role of virtual water in constructing structures of power}

The first section of this article opened the black box of the concept of virtual water and of the manner it is assessed quantitatively. It identified the underlying hypotheses. The second section of this article followed in detail the actual trajectory of water from the point it leaves the soil up to the point it evapotranspirates through the leaves of cultivated plants or otherwise leaves the system. This detailed study invalidated the hypotheses both underlying the concept of virtual water and its calculation method. We now integrate elements of structuration theory to an STS approach in order to explore the manner power relations pervade the processes of coproduction of a scientific discourse in the construction of legitimacy in water use.

The present formulation of virtual water limits the type of criticism that can be formulated concerning water use. It makes those actors deploying their strategy at the national scale very visible and legitimate. For example, al-Bira wastewater treatment plant has been the first to operate in the West Bank since 2013. It produces treated wastewater still unused in agriculture. Consequently, the project of a pipeline bringing treated wastewater from alBira, located at about 800 meters altitude directly to al-'Uja, located at about $200 \mathrm{~m}$ below sea level, appears as enhancing water efficiency. This treated wastewater is presently released in the environment. It penetrates the soil and is used as green water by nature and by a succession of farmers between the ridge, where al-Bira is located, and the Jordan Valley. In 
other words, this water is used many times by a variety of actors, whether human or nonhuman. The project of a pipeline would eliminate all of these uses, allowing only a single use before water trickles towards the Dead Sea acting as a sink. Treated wastewater is a new resource, a typical paracommon, which is the target of competing appropriation mechanisms. The pipeline would reduce the overall efficiency of water use, yet thanks to the calculation method to assess virtual water, it would appear as raising the overall efficiency of water use at the national level.

Those actors promoting the project of a pipeline to bring treated wastewater to al-'Uja include individuals who purchased cheap land around that village when its spring nearly disappeared in 2011. (Trottier, 2013, p. 163) Well versed in "donor speak" and well integrated in the social arenas that elaborate projects for foreign donors, these Palestinian investors don't reside in al-'Uja. Foreign donors have devoted very large sums to the Palestinian water sector since 1994. (Le More, 2008) Harnessing the discourse of virtual water allows individuals wishing to access those funds to shroud their projects in an illusion of water efficiency. Similarly, as the idiom of virtual water projects uniformity over the entire territory, it automatically legitimates an institution such as the Palestinian Water Authority (PWA) which produces a discourse aimed at the national scale. Yet the law and decree that it upholds don't harness the various forms of local water management. As a result, they are neither implemented nor implementable.

The present formulation of virtual water makes those actors deploying their strategy at the scale of a village invisible and illegitimate. This phenomenon is akin to the manner global food models make smallholders invisible. (Leblond and Trottier, 2016) Virtual water is calculated as a stock embedded in the land which disappears through evapotranspiration. Farmers and other actors interacting with this flow between these two points play a crucial role. Their actions determine which part of the flow is directed to one or other of the 16 
possible trajectories. At first sight, their management may seem inefficient. Yet, when they direct water into a trajectory that benefits wild plants, the neighboring village's well or their neighbor's field, they are, however inadvertently, maintaining a solidarity with human and nonhuman neighbors. Their actions are portrayed as inefficient by the idiom of virtual water. It hypothesizes that food security can only result from importing food from abroad that embeds less virtual water. Much of what appears to be inefficient water management contributes to other mechanisms that maintain local food security. Often, "improvements" to the irrigation infrastructure to enhance water efficiency proved detrimental to mechanisms that maintain local food security. For example, switching an open canal system to a pressurized pipe system ensures a greater portion of the incoming water leaves through evapotranspiration of the crop. But it decreases the portion of water that seeped in the ground and contributed to pasture for sheep, to khubbiza or to the neighboring village's well.

As an interpretive scheme, virtual water sheds much light on the interactions between the construction of a structure of signification and the accompanying construction of a structure of domination. Structuration theory shows that discursive mechanisms link structure and agency. (Jabri, 1996) The production of meaning occurs through the construction of interpretive schemes which, when hegemonic, support a structure of signification. The latter reinforces the structure of domination. These structural properties of social systems constrain agency. They determine the degree of freedom of the actors, their capacity to act and even to think and be aware of their condition. In the case of virtual water, the prolific publications, detailing the stock embedded in various crops, support a structure of domination where international trade ensures both food security and sustainable development. Within such a structure of domination, smallholders are doomed. Within the accompanying structure of signification, their contribution to food security and sustainable development has never been 
considered. The manner virtual water is framed makes their interactions with water flows invisible.

Virtual water constitutes an interpretive scheme. It plays a role in a specific structure of signification where agribusinesses bent on exportation are considered the only legitimate, successful forms of farming. As an interpretive scheme produced by scientists, virtual water plays a role at the interface between our representation of nature and our construction of the social order. This interpretive scheme is thus an important part of the coproduction of both the discourse on efficient use of water in agriculture and the political management of water deemed to be sound. Any discourse concerning the environment relies on an underlying ideology. (Forsyth, 2003) When knowledge concerning the environment circulates and is implemented, it is unavoidably transformed. (Goldman, Nadasdy et al., 2011) Similarly, an outwardly neutral indicator of water efficiency becomes a ruthless tool to classify farmers as either "successful" or "inefficient" and to justify policies promoting only the first category. Map 4 shows the virtual water embedded in cucumbers produced by farmers selected on the basis of their classical efficiency. 


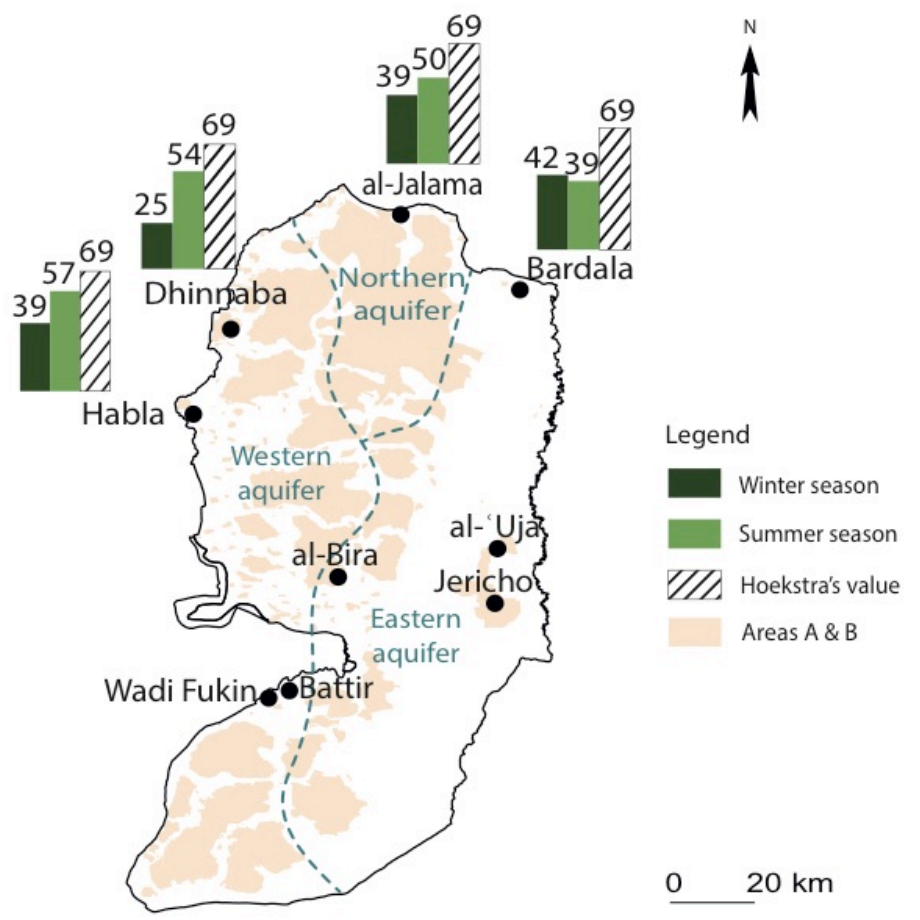

Map 4: Average quantity ( $\mathrm{m}^{3} /$ ton) of water consumed by 1 ton of cucumbers produced by "efficient" farmers in four villages located across the three main aquifers of the West Bank

The representation in Map 4 differs significantly from that of Map 1. In all four villages, some farmers achieve rates of virtual water that are lower than that calculated using the standard method. Such farmers are portrayed as efficient and successful. A public policy based on the concept of virtual water would seek to support them. Yet, these farmers may not necessarily be integrated in the overall redistribution of the flow of water that inevitably occurs between the origin of water and the plant, in an especially beneficial manner for their local environment. Their actual contribution to food security may be much less than that of another farmer deemed inefficient according to this indicator. The idiom of virtual water nevertheless portrays them as the most capable of contributing to food security because the stock of water 
involved in producing their crop is smaller than the stock of water other farmers from their villages need to produce the same crop. As such, virtual water is not an appropriate indicator to discuss food security. It ignores the benefits of non-process beneficial consumption of water, allowing, for example, lemon trees and khubbiza to grow.

The calculation of virtual water as a stock feeds into the prevalent representations of water negotiations between Israel and the Palestinian Authority. Instead of focusing on the joint management of an uninterrupted flow, these negotiations have always treated water as a stock. The Oslo agreements attributed fixed volumes of water from each of the three West Bank aquifers to each of the two parties. Such a representation of water as an immobile resource is preposterous. For example, in Habla, farmers do not harvest rainwater from the rooftops of their greenhouses because the local wells provide water at $1 \mathrm{New}$ Israeli Shekel per cubic meter, making the equipment to collect rainwater uncompetitive. In many plots, rainwater is channeled straight from greenhouses' rooftops into a ditch that brings it into Israel. The water Habla farmers bring to their plots is counted as part of the quantity attributed to the Palestinians, yet, once it has penetrated the ground, it flows into Israel. This phenomenon is even larger in locations were submersion irrigation is practiced, such as in Battir, and Wadi Fukin villages, situated next to the Green Line that demarcates the limit of Israel according to the 1949 armistice agreement.

Overcoming the limitations imposed by such a narrowly defined structure of signification is necessary. The danger of naturalizing the policy discourse based on virtual water is real. Naturalizing its specific definition of efficiency empowers state engineers as the only persons capable of establishing water rights and distribution schedules. (Boelens and Vos, 2012, p. 22, 24) It denies the knowledge accumulated by farmer managed institutions that have sometimes proved their resiliency over centuries. It legitimates a structure of domination where a merchant economy alone exists whereas Palestinian irrigating farmers, 
like millions of smallholders around the world, are very much embedded in a human economy. A merchant economy rearranges goods and its actors use money to accumulate wealth. A human economy creates, destroys and repositions humans, using money to create, maintain or interrupt relations among persons. (Graeber, 2011) A large part of food security for Palestinians depends on a human economy that involves "inefficient" uses of water. Palestinian smallholders are facing the penetration of a merchant economy, especially since 2008, into domains previously managed by a human economy. The idiom of virtual water prevents us from understanding how this is affecting them.

\subsection{Epistemic communities and Palestinian water}

The literature on Palestinian water originates from three main epistemic communities. Within area studies, water is usually treated as an immobile resource which needs to be carved out quantitatively between two opposing parties, Israel and the Palestinian Authority. Many practitioners subscribe to this representation. Saeb Erekat, the present secretary general of the Palestinian Liberation Organization, stated in 2015 that establishing the borders would automatically solve the water problem. This would be the case if water remained static underground. But water keeps flowing irremediably, borders or no borders.

Within the water engineering literature, the concept of virtual water is so entrenched that framing water as a stock that can be exchanged through international trade is taken for granted. Virtual water is presented as an inexpensive adjustment deemed necessary because "[A]ny advances made in irrigation will translate into gains in other sectors - which often have higher economic returns or added value like industry, public water supply and sanitation or environmental services - which at present are not benefiting globally from water captured by irrigation.” (Lopez-Gunn and Llamas, 2008, p. 228) Such wishful thinking is easily invalidated by field observations. Most often, "advances in irrigation" mean that water 
previously wasted in the process is redirected from one of the 16 possible trajectories into the only one that leads to the cultivated crop. It rarely leads to an increase in water availability for other users. (Lankford, 2013) This was demonstrated in Jericho in the 1990s as detailed earlier in this article. It was also demonstrated in Yemen when free American grain entered the country as food aid, leading farmers in the Sa'ada basin to forgo the irrigation of wheat and turn to growing alfalfa, a crop that consumes much more water. (Lichtenthaler, 2003) Virtual water has been described as a myopic notion. (Wichelns, 2011) Farsightedness may describe it better. It allows a vision from afar, but so blurry a representation from up close that it becomes quite misleading.

Within the political ecology literature, or more broadly, the social science literature, the narrative opposing Capital and communities often dominates. "Communities" are usually not defined, but expected to protest against large companies such as multinational food-chain companies. (Vos and Hinojosa, 2016) Such a literature identifies the "paradigm of bourgeois economics hiding in virtual water." (Gialis and Mavroudeas, 2014, p. 9) It usually remains remote from fieldwork and rarely explores the "communities" that are expected to protest against Capital. It often projects upon the commons a will to resist capitalism. (Dardot and Laval, 2015) Yet, fieldwork usually dispels this idea. A community that constructs a common concerning an object, such as Palestinian farmers do concerning water, seek an interaction with the state, when one exists, and with capitalism, concerning other objects. It doesn't seek to organize resistance against the state. Typically, Palestinian farmers who participate in the careful management of their commons whether they be springs or well companies, also receive tap water from either Mekorot, the Israeli national water company or from the municipality. The latter is usually supplied by a variety of sources, including Mekorot. When farmers rely on the free water from a spring managed as a common, they see no contradiction 
with selling their products on the market. Their maintenance of their common usually does not mean an opposition to capitalism outside of that common.

\section{Conclusion}

Opening the black box of virtual water allowed us to identify the underlying hypotheses both of the concept of virtual water and the method to assess it quantitatively. Our field research invalidated these hypotheses. Integrating structuration theory to an STS approach proved useful to explore the manner the coproduction of an interpretive scheme, virtual water, is linked to the construction of a structure of power. Virtual water, as an interpretive scheme, feeds a structure of signification that determines which farmers are "successful" because they are "efficient". This article demonstrated that the coproduction of virtual water as a concept legitimizes export oriented agribusinesses and portrays smallholders as inefficient. It makes their contribution to food security and environmental sustainability invisible.

Our approach frees us from such representations as it treats water as a flow. Water "lost" between source and plant, by one farmer, often feeds another user, whether human or non human. The decision processes, determining the various trajectories of water between source and plant, impact the virtual water content of a crop far more than climatic or agronomic variables. Such decision processes are both individual and collective in the Palestinian context. Analyzing them reveals the multiple interactions within agriculture that ensure food security, environmental sustainability, even housing security. It demonstrates that the appropriate scalar level to consider efficiency in water use is determined by the path water follows between source and plant.

Policies based on standard calculations of international virtual water flows unavoidably harm smallholders because it ignores the manner such farmers are embedded in 
redirecting water flows. Understanding the manner the coproduction of this concept is linked to the coproduction of a structure of domination is necessary to understand the context within which smallholders exert their agency. It allows us to understand their constraints and their definitions of efficiency. It allows us to understand their contribution to sustainable development. Policies need to build on such mechanisms.in order to succeed.

\section{List of References}

Allan, J. A., 1992. Substitutes for water are being found in the Middle East and North Africa. Geojournal 28(3), 375-385.

Barnes, J., 2013. Water, water everywhere but not a drop to drink: the false promise of virtual water. Critique of Anthropology 33(4), 371-389.

Boelens, R., Vos, J., 2012. The danger of naturalizing water policy concepts: Water productivity and efficiency discourses from field irrigation to virtual water trade. Agricultural Water Management 108, 16-26.

Chapagain, A. K., Hoekstra, A. Y., 2004. Water Footprints of Nations. The Value of Water Research Report Series, 16. Delft: Unesco-IHE Institute for Water Education, The Netherlands.

Chapagain, A. K., Hoekstra, A. Y., 2011. The blue, green and grey water footprint of rice from production and consumption perspectives. Ecological Economics 70(4), 749-758.

Chapagain, A. K., Hung, P. Q., 2002. Virtual Water Trade. A quantification of virtual water flows between nations in relation to international crop trade. The Value of Water Research Report Series, 11. Delft: Unesco-IHE Institute for Water Education, The Netherlands.

Chapagain, A. K., Orr, S., 2009. An improved water footprint methodology linking global consumption to local water resources: A case of Spanish tomatoes. Journal of Environmental Management (90), 1219-1228.

Dabrowski, J. M., Masekoameng, E., et al., 2009. Analysis of virtual water flows associated with the trade of maize in the SADC region: importance of scale. Hydrology and Earth System Sciences 13(10), 1967-1977.

Dardot, P., Laval, C., 2015. Commun. Essai sur la révolution au XXIè siècle. La Découverte, Paris.

Espeland, W., 1998. The Struggle for Water, Politics, Rationality and Identity in the American Southwest. The University of Chicago Press, Chicago. 
Fernandez, M. D., Bonacela, S., et al., 2010. Measurement and estimation of plastic greenhouse reference evapotranspiration in a Mediterranean climate. Irrigation Science 28(6), 497-509.

Fernandez, S., 2008. L'eau virtuelle, quelle réalité? Maghreb-Machrek (196), 45-62.

Forsyth, T., 2003. Critical Political Ecology: the politics of environmental science. Routledge, London.

Forsyth, T., Levidow, L., 2015. An Ontological Politics of Comparative Environmental Analysis: The Green Economy and Local Diversity. Global Environmental Politics 15(3), 140-151.

Gialis, S., Mavroudeas, S., 2014. Virtual Water: More Heat than Light? Capitalism Nature Socialism 25(2), 60-74.

Goldman, M., Nadasdy, P., et al., 2011. Knowing nature : conversations at the intersection of political ecology and science studies. Chicago, Ill. ; London, University of Chicago Press.

Graeber, D., 2011. Debt The first 5,000 years. Melville House, New York.

Harvey, D., 2010. The Enigma of Capital and the Crisis of Capitalism. Profile Books, London.

Hoekstra, A. Y., Chapagain, A. K., et al., 2011. The Water Footprint Assessment Manual: Setting the Global Standard. London, Earthscan.

Hoekstra, A. Y., Hung, P. Q., 2005. Globalisation of water resources: international virtual water flows in relation to crop trade. Global Environmental Change 15(1), 45-56.

Jabri, V., 1996. Discourses on Violence Conflict analysis reconsidered. Manchester University Press, Manchester.

Jasanoff, S., 2004. States of knowledge : the co-production of science and social order. Routledge, London; New York.

Jasanoff, S., 2017. Science and Democracy. The Handbook of Science and Technology Studies. Fourth edition. The MIT Press, Cambridge MA, 259-288.

Lankford, B., 2013. Resource Efficiency Complexity and the Commons. Routledge, London.

Latour, B., 1987. Science in Action. Harvard University Press, Cambridge, Massachusetts.

Le More, A., 2008. International assistance to the Palestinians after Oslo : political guilt, wasted money. Routledge, London. 
Leblond, N., Trottier, J., 2016. Performing an Invisibility Spell: Global Models, Food Regimes and Smallholders. International Journal of Sociology of Agriculture and Food 23(1), 21-40.

Lichtenthaler, G., 2003. Political Ecology and the Role of Water, Environment, Society and Economy in Northern Yemen. Ashgate Publishing Limited, Aldershot.

Lopez-Gunn, E., Llamas, M. R., 2008. Rethinking water scarcity: Can science and technology solve the global water crisis? Natural Resources Forum 32(1), 228-238.

Mol, A., 1999. Ontological politics: A word and Some Questions. The Sociological Review $47,75-89$.

Perry, C., 2014. Water footprints: Path to enlightenment or false trail? Agricultural Water Management 134, 119-125.

Rajagopalan, R., Nelson, A., Fujimura, J., 2017. Race and Science in the Twenty-First Century. The Handbook of Science and Technology Studies. Fourth Edition. The MIT Press, Cambridge MA, 349-378.

Trottier, J., 1999. Hydropolitics in the West Bank and Gaza Strip. PASSIA, Jerusalem.

Trottier, J., 2013. The social construction of water management at the intersection of international conflict. The Case of Al Auja. Eurorient (44), 161-181.

Trottier, J., 2015. Le rapport à l'eau et à la terre dans la construction de territoires multisitués: le cas palestinien. L'Espace Géographique 2, 103-114.

Vos, J., Hinojosa, L., 2016. Virtual Water Trade and the Contestation of Hydrosocial Territories. Water International 41(1), 37-53.

Wichelns, D., 2011. Virtual water and water footprints: Compelling notions but notably flawed. GAIA 20(3), 171-175.

Wichelns, D., 2015. Virtual Water and Water Footprints: Overreaching into the Discourse on Sustainability, Efficiency and Equity. Water Alternatives 8(3), 396-414. 